\title{
UPAYA MENINGKATKAN KEMAMPUAN TEKNIK DASAR PASSING ATAS DAN PASSING BAWAH BOLA VOLI MELALUI METODE INOVATIF MODIFIKASI BOLA DI KELAS V SD NEGERI 26 LUBUKLINGGAU
}

\author{
Darmawati \\ Guru SD Negeri 26 Lubuklinggau \\ darmawati@gmail.com
}

\begin{abstract}
ABSTRAK
Dalam pelaksanaan pembelajaran PJOK pada permainan bola voli pada SD Negeri 26 Lubuklinggau masih mendapat kendala bahkan dapat dikatakan belum berhasil. Penelitian ini bertujuan untuk mendapatkan informasi dan membahas tentang upaya meningkatkan kemampuan teknik dasar passing atas dan passing bawah bola voli melalui metode inovatif modifikasi bola siswa kelas V SD Negeri 26 Lubuklinggau Tahun Pelajaran 2017/2018 setelah diberikan. Penelitian ini akan dilaksanakan pada siswa kelas V SD Negeri 26 Lubuklinggau yang terletak di Jalan Kenanga II Kel. Kenanga Kec. Lubuklinggau Utara II kota Lubuklinggau, pada materi pembelajaran bola besar bola voli. Pelaksanaan penelitian dilakukan dalam waktu tiga bulan, yakni bulan September sampai dengan bulan November 2017. Subjek penelitian ini adalah siswa kelas V SD Negeri 26 Lubuklinggau Tahun pelajaran 2017/2018 dengan jumlah 25 orang siswa. Dari hasil kegiatan pembelajaran yang telah dilakukan selama dua siklus, dan berdasarkan seluruh pembahasan serta analisis yang telah dilakukan dapat disimpulkan bahwa pembelajaran dengan metode Inovatif Modifikasi Bola memiliki dampak positif dalam meningkatkan hasil belajar siswa yang ditandai dengan peningkatan ketuntasan belajar siswa dalam setiap siklus.
\end{abstract}

Kata Kunci: PJOK, Passing Atas dan Passing Bawah, Metode Inovatif

\begin{abstract}
In the implementation of PJOK learning in volleyball games at SD Negeri 26 Lubuklinggau, it still faces obstacles and can even be said to have not been successful. This study aims to obtain information and discuss efforts to improve the basic technical skills of volleyball over and under passing through an innovative method of ball modification for class V students of SD Negeri 26 Lubuklinggau in the 2017/2018 academic year. This research will be carried out on fifth grade students of SD Negeri 26 Lubuklinggau which is located on Jalan Kenanga II Kel. Kenanga Kec. Lubuklinggau Utara II, Lubuklinggau city, on the learning material for volleyball big balls. The research was carried out within three months, from September to November 2017. The subjects of this study were the fifth grade students of SD Negeri 26 Lubuklinggau academic year 2017/2018 with a total of 25 students. From the results of learning activities that have been
\end{abstract}


carried out for two cycles, and based on all the discussions and analyzes that have been carried out, it can be concluded that learning with the Ball Modification Innovative method has a positive impact in increasing student learning outcomes which is marked by an increase in student learning completeness in each cycle.

Keywords: PJOK, Upper and Lower Passing, Innovative Methods

\section{PENDAHULUAN}

Undang-undang

Indonesia No. 3 Tahun 2005 tentang

Sistem Keolahragaan Nasional mengisyaratkan masyarakat

mempunyai hak untuk berperan aktif dalam mengembangkan keolahragaan nasional sesuai dengan bakat dan kemampuan dibidangnya masingmasing, memilih dan mengikuti jenis dan cabang olahraga yang sesuai dengan bakat dan minatnya.

Pendidikan merupakan salah satu kegiatan untuk mencapai tujuan nasional Indonesia, yaitu mencerdaskan kehidupan bangsa. Salah satu usaha yang dapat dilakukan dalam rangka mencerdaskan kehidupan bangsa adalah melalui pendidikan. Pendidikan diharapkan dapat meningkatkan kualitas hidup, baik jasmaniah maupun rohaniah, untuk kehidupan yang akan datang, sehingga pendidikan menjadi salah satu kebutuhan pokok bagi setiap manusia, masyarakat, bangsa dan negara. Pendidikan Jasmani, Olahraga dan
Kesehatan merupakan bagian integral dari pendidikan secara keseluruhan, bertujuan untuk mengembangkan aspek kebugaran jasmani, keterampilan gerak, keterampilan berfikir kritis, keterampilan sosial, penalaran, stabilitas emosional, tindakan moral, aspek pola hidup sehat dan pengenalan lingkungan bersih melalui aktivitas jasmani, olahraga dan kesehatan terpilih yang direncanakan secara sistematis dalam rangka mencapai tujuan pendidikan nasional Depdiknas (2003: 3).

Di sekolah dasar pembelajaran permainan yang menggunakan bola besar diantaranya adalah bola voli merupakan salah satu materi ajar, yakni mrmpraktikkan dasar-dasar permainan bola voli. Untuk dapat memainkan bola voli kita harus terlebih dahulu menguasi dasar-dasar permainan bola voli itu sendiri. Dasar-dasar permainan bola voli adalah service, Passing atas, Passing bawah, bloking/membendung dan smash. Permainan bola voli dapat berjalan dengan baik apabila siswa 
sudah menguasai dasar gerak hasil pembelajaran passing atas dan permainan bola voli. Penguasaan dasar passing bawah bola voli yakni dengan gerak sangat penting agar bisa bermain model pembelajaran inovatif bola voli dengan baik. Untuk menggunakan bola voli modifikasi. menguasai dasar gerak tersebut Dalam pembelajaran teknik dasar diperlukan latihan-latihan dasar gerak hususnya passing atas dan passing secara terus menerus dan sunggung- bawah guru kadang kala kurang sungguh supaya dapat menguasai dasar gerak bola voli itu dengan mudah.

Sebenarnya untuk siswa sekolah dasar permainan bola voli sudah disederhanankan yakni dengan permainan bola voli mini. Lapangan yang lebih kecil dengan bola standar bola voli mini yang lebih kecil pula akan memudahkan siswa untuk mempelajarinya. Dalam pelaksanaan pembelajaran PJOK pada permainan bola voli pada SD Negeri 26 Lubuklinggau masih mendapat kendala bahkan dapat dikatakan belum berhasil. Berdasarkan data siswa kelas V dari jumlah siswa 25 orang yang mampu melakukan teknik dasar passing atas dan passing bawah dengan benar hanya 10 orang siswa $(40,00 \%)$. Jadi siswa yang belum dapat melakukan passing atas dan passing bawah permainan bola voli dengan benar berjumlah 15 orang siswa $(60,00 \%)$.

Dalam hal ini penulis merasa perlu dan tertarik untuk meningkatkan mampu mengembangkan keterampilan mengajar yang dapat menarik perhatian siswa dan mendapatkan hasil yang optimal. Menggunakan kata lain pembelajaran yang dilakukan guru masih bersifat konvensional, yakni hanya terbatas pada penyampaiaan teknik dasar dengan menggunakan bola standar yang mengakibatkan hasilnya belum dapat diharapkan.

Oleh sebab itu agar pembelajaran PJOK menjadi pembelajaran yang aktif, kreatif, efektif dan menyenangkan dapat dilakukan dengan berbagai cara, salah satunya dengan penerapan metode Inovativ. Pada dasarnya, Metode Inovatif berasal dari kamus bahasa Indonesia (2003) kata "inovasi" mengangdung arti pengenalan hal-hal yang baru atau pembaharuan". Inovasi juga berarti penemuan baru yang berbeda dari yang sudah ada atau yang sudah dikenal sebelumnya (gagasan, metode, atau alat). Jadi pembelajaran inovatif dapat 
diartikan sebuah pembelajaran yang menggunakan strategi/metode baru yang dihasilkan dari penemuannya sendiri atau menerapkan metode baru yang ditemukan oleh para pakar dan didesain sedemikian rupa sehingga dapat menciptakan pembelajaran yang kondusif. Dalam pelaksanaan penelitian ini guru akan memperoleh kesimpulan terhadap hasil proses pembelajran sehingga guru dapat mengetahui siswa yang dapat melakukan passing atas dan passing bawah dengan benar, bahkan guru dapat mengetahui siswa yang perlu mendapat bantuan khusus, terlebih penting guru dapat memperoleh informasi dan umpan balik terhadap pelajaran yang telah diberikan.

Berdasarkan latar belakang diatas dapat dirumuskan suatu masalah yaitu: "bagaimanakah

cara meningkatkan kemampuan teknik dasar passing atas dan passing bawah bola voli melalui metode inovatif modifikasi bola siswa kelas V SD Negeri 26 Lubuklinggau?”.

Berdasarkan masalah penelitian, maka penelitian ini bertujuan untuk mendapatkan informasi dan membahas tentang upaya meningkatkan kemampuan teknik

dasar passing atas dan passing bawah bola voli melalui metode inovatif modifikasi bola siswa kelas V SD Negeri 26 Lubuklinggau Tahun Pelajaran 2017/2018 setelah diberikan. Dalam proses belajar di sekolah siswa memerlukan bimbingan dan arahan pembelajaran dari guru untuk membangkitkan motivasi siswa dalam belajar sehingga prilaku yang diharapkan dan meningkatkan kemampuan hasil belajar siswa. Menurut Gagne (dalam Sulham,Najib, 2006:5) belajar adalah proses perubahan tingkah laku yang meliputi perubahan kecendrungan manusia, seperti sikap, minat atau nilai perubahankemampuannya, yakni meningkatkan kemampuan untuk melakukan jenis ferformance (kinerja). Dari segi guru proses belajar dapat memahami apa yang tampak lewat prilaku siswa mempelajari bahan pelajaran. Prilaku belajar siswa juga tampak pada tindak-tindak belajar pada saat berlangsungnya pelajaran olahraga. Prilaku belajar siswa merupakan respons siswa terhadap tindakan pembelajaran dari guru. Senada dengan pendapat Hasan Alwi (2007:17), pembelajaran adalah proses, 
cara, perbuatan menjadikan orang atau makhluk hidup belajar.

Permainan bola voli adalah suatu jenis olah raga permainan. Permainan ini dimainkan oleh dua regu yang saling berhadapan yang masingmasing regu terdiri dari enam pemain, setiap regu berusaha untuk dapat memukul dan menjatuhkan bola ke dalam lapangan melewati di atas jaring atau net dan mencegah pihak lawan dapat memukul dan menjatuhkan bola ke dalam lapangannya.(Aip Syarifuddin dan Muhadi, 1991: 183).

Permainan bola voli merupakan permainan yang tidak mudah untuk dilakukan setiap orang. Dalam permainan ini dibutuhkan koordinasi gerak yang baik yang dapat digunakan secara efektif dan efisien dan tentunya sangat mendukung bagi tim saat permainan berlangsung. Menurut Nuril Ahmadi (2007: 20) permainan bola voli merupakan permainan yang kompleks yang tidak mudah dilakukan oeh setiap orang. Sebab, dalam permainan voli dibutuhkan koordinasi gerak yang benar-benar bisa diandalkan untuk melakukan semua gerakan yang ada dalam permainan bola voli. Salah satu faktor penting yang mendukung dalam permainan bola voli adalah kondisi fisik seorang pemain. Menurut Suharno (1982: 21) kondisi fisik secara umum meliputi kekuatan, daya tahan, kecepatan, kelincahan dan kelentukan.

Teknik dasar dalam permainan bolavoli menurut Nuril Ahmadi (2007: 20), "Dalam permainan bola voli ada beberapa bentuk teknik dasar yang harus dikuasai. Teknk-teknik dalam permainan bola voli terdiri atas servis, passing bawah, passing atas, block, dan smash". Untuk dapat bermain bolavoli dengan baik diperlukan penguasaan teknik dasar.

Suharno (1982:35) menyatakan bahwa "Teknik dasar adalah suatu proses melahirkan keaktifan jasmani dan pembuktian dalam praktek dengan sebaik mungkin untuk menyelesaikan tugas yang pastinya dalam cabang permainan bola volley."

Menurut kamus bahasa Indonesia (2003) kata "inovasi" mengandung arti pengenalan hal-hal yang baru atau pembaharuan". Inovasi juga berarti penemuan baru yang berbeda dari yang sudah ada atau yang sudah dikenal sebelumnya (gagasan, metode, atau alat). Jadi pembelajaran inovatif dapat diartikan sebuah pembelajaran yang menggunakan 
strategi/metode baru yang dihasilkan dari penemuannya sendiri atau menerapkan metode baru yang ditemukan oleh para pakar dan didesain sedemikian rupa sehingga dapat menciptakan pembelajaran yang kondusif.

Pembelajaran inovatif juga mengandung arti pembelajaran yang dikemas oleh guru atau instruktur lainnya yang merupakan wujud gagasan atau teknik yang dipandang baru agar mampu menfasilitasi siswa untuk memperoleh kemajuan dalam proses dan hasil belajar. Pembelajaran inovatif bisa mengadaptasi dari model pembelajaran yang menyenangkan. "Learning is fun" merupakan kunci yang diterapkan dalam pembelajaran inovatif. Jika siswa sudah menanamkan hal ini di pikirannya tidak akan ada lagi siswa yang pasif di kelas, perasaan tertekan, kemungkinan kegagalan, keterbatasan pilihan, dan tentu saja rasa bosan. Membangun metode pembelajaran inovatif sendiri bisa dilakukan dengan cara diantaranya mengakomodir setiap karakteristik diri. Artinya mengukur daya kemampuan serap ilmu masing-masing orang.

Syah dan Kariadinata (2009:

16) Pembelajaran inovatif dapat menyeimbangkan fungsi otak kiri dan kanan apabila dilakukan dengan cara mengintegrasikan media/alat bantu terutama yang berbasis teknologi baru/maju ke dalam proses pembelajaran tersebut. Sehingga, terjadi proses renovasi mental di antaranya membangun rasa pecaya diri siswa. Penggunaan bahan pelajaran, software multimedia, dan microsoft powerpoint merupakan salah satu alternatif. Pembelajaran yang inovatif diharapkan mampu membuat siswa yang mempunyai kapasitas berpikir kritis dan terampil dalam memecahkan masalah. Siswa yang seperti ini mampu menggunakan penalaran yang jernih dalam proses memahami sesuatu dan mudah dalam mengambil pilihan serta membuat keputusan. Hal itu dimungkinkan karena pemahaman interkoneksi di antara system atau subsistem terkait dengan persoalan yang dihadapinya. Juga terlihat kemampuan mengidentifikasi dan menemukan pertanyaan tepat yang dapat mengarah kepada pemecahan masalah secara lebih baik. Informasi yang diperolehnya akan dikerangkakan dan dianalisis sehingga akan dapat menjawab pertanyaan-pertanyaan tersebut dengan baik. Pembelajaran 
yang inovatif juga tercermin dari hasil yang diperlihatkan siswa yang komunikatif dan kolaboratif dalam mengartikulasikan pikiran dan gagasan secara jelas dan efektif melalui tuturan lisan dan tulisan. Siswa dengan karakteristik semacam ini dapat menunjukkan kemampuan untuk bekerja secara efektif dalam tim yang beraneka, untuk memainkan fleksibilitas dan kemauan berkompromi dalam mencapai tujuan bersama.

Dalam proses belajar mengajar ditingkat sekolah dasar hususnya pada siswa SD Negeri 26 Lubuklinggau masih belum menampakkan keberhasilan. Keberhasilan terkendala dengan sulitnya siswa dalam melakukan passing atas dan passing bawah, hal inilah yang mendorong peneliti untuk melakukan tindakan yaitu dengan menggunakan metode lain, yakni dengan metode inovatif modifikasi alat dalam hal ini adalah bola.

Mengacu pada pendapat Sukidin, Basrowi, Suranto (2007:91) Tujuan modifikasi adalah untuk pemercepatan mencapai tujuan, sekiranya cara yang dilakukan kurang menjamin dan lamban menimbulkan perubahan. Modifikasi juga diungkapkan Ibrahim (2001:111) dalam memilih kegiatan olahraga yang dapat membina kerjasama dan kompetisi sekaligus dengan memodifikasi atau jumlah pemainnya.

Berdasarkan pendapat-pendapat di atas peneliti berkesimpulan untuk memudahkan mempelajari permainan bola voli dapat dimainkan dan dipelajari dengan cara memodifikasi alat dalam hal ini adalah bola. Bola yang dimodifikasi adalah bola voli mini standar yang kulit lapisan luarnya telah terlepas sebagian, sehingga siswa termotivasi dan tidak merasa takut untuk berlatih melakukan passing atas dan passing bawah.

\section{METODE}

Dalam penelitian ini peneliti menggunakan metode penelitian tindakan kelas (Classroom Action Research) yang akan dilaksanakan pada siswa kelas V SD Negeri 26 Lubuklinggau, dengan alas an bahwa bahwa siswa kelas $\mathrm{V}$ belum dapat melakukan passing atas dan passing bawah dengan teknik yang benar.

Penelitian tindakan ini bertujuan untuk meningkatkan hasil pembelajaran passing atas dan passing bawah dengan melibatkan pengajar dan 
peserta didik. Dalam pelaksanaan September sampai dengan bulan peneliti merencanakan penelitian November 2017.

sampai dengan dua siklus dan setiap Subjek penelitian ini adalah siklus memiliki tindakan yang berbeda dengan proses penelitian sebelumnya. siswa kelas V SD Negeri 26 Lubuklinggau Tahun Pelajaran Peneliti juga merencanakan 2017/2018 dengan jumlah 25 orang akan melakukan tahapan yang setiap siswa. Indikator keberhasilan dalam siklusnya terdiri dari :Perencanaan, penelitian ini apabila siswa telah berisikan rencana tindakan yang akan mencapai ketuntasan kemampuan dilaksanakan untuk meningkatkan teknik passing atas dan passing bawah pembelaajaran teknik dasar passing dengan KKM sama dengan di atas 75 atas dan passing bawah dengan bola dan sebanyak $85 \%$ siswa tuntas secara standar. Tindakan, berisikan kegiatan klasikal.

yang dilakukan peneliti sebagai upaya meningkatkan hasil pembelajaran passing atas dan passing bawah dengan memodifikasi bola voli. Observasi, pengamatan atau perubahan tindakan yang dilakukan siswa. Refleksi, peneliti mengkaji setiap hasil dan (observation) dan perenungan perubahan dari tindakan yang (reflection). Selanjutnya diuraikan dilakukan. langkah - langkah kegiatan yang

Penelitian ini akan dilaksanakan dilaksanakan dari satu kali pertemuan pada siswa kelas V SD Negeri 26 disetiap siklus yang meliputi: Lubuklinggau yang terletak di Jalan perencanaan, pelaksanaan, obsevasi, Kenanga II Kel. Kenanga Kec. dan refleksi.

Lubuklinggau Utara II kota PEMBAHASAN

Lubuklinggau, pada materi Siklus 1 pembelajaran bola besar bola voli.

Siklus I dilaksanakan pada Pelaksanaan penelitian dilakukan tanggal 19 September 2017, pada dalam waktu tiga bulan, yakni bulan siklus ini dilaksanakan tindakan dengan cara : Melakukan passing atas 
dan passing bawah pada lapangan dengan model pembelajaran inovatif bola voli modifikasi (bola voli mini standar yang kulit luar telah dilepas). Langkah-langkah adalah sebagai berikut: Peserta didik diberi motivasi atau rangsangan untuk memusatkan perhatian pada topik materi :Passing atasdengan cara :pemberian contohcontoh materi :Passing atasuntuk dapat dikembangkan peserta didik, dari media interaktif.Tahap motivasi siswa melakukan tindakan passing atas dan passing bawah. Tahap tindakan siswa tetap diberikan motivasi agar dapat melakukan passing atas dan passing bawah dengan teknik yang benar dengan menggunakan bola modifikasi, pada saat ini siswa melakukan passng atas dengan bola diover oleh teman dengan menggunakan net sebagai rintangan.

Pengamatan kegiatan siklus I dilakukan secara bersama-sama oleh peneliti dan guru kolabolator, dalam hal ini guru kolaborator sendiri yang bertindak sebagai guru pengamat. Kegiatan peneliti siswa selama proses pembelajaran berlangsung diamati melalui lembar pengamatan guru dan lembar pengamatan siswa. Berikut disajikan pada table 1 hasil pengamatan kegiatan guru siklus I .

Tabel 1 Hasil Observasi Kegiatan Guru Siklus I

\begin{tabular}{|c|c|c|c|}
\hline \multirow{2}{*}{ No. } & \multirow{2}{*}{ Aspek Yang Diamati } & \multicolumn{2}{|c|}{ Dilaksanakan } \\
\hline & & $\mathrm{Ya}$ & Tidak \\
\hline A & $\begin{array}{l}\text { Kegiatan Pendahuluan } \\
\text { Formasi Barisan } \\
\text { Berdoa } \\
\text { Absensi } \\
\text { Pemanasan }\end{array}$ & $\begin{array}{l}\sqrt{ } \\
\sqrt{ } \\
\sqrt{ } \\
\sqrt{ }\end{array}$ & \\
\hline B & $\begin{array}{l}\text { Guru menjelaskan tentang } \\
\text { Passing atas dan passing } \\
\text { bawah dalam permainan } \\
\text { bola voli } \\
\text { Guru melatih cara } \\
\text { melakukan Passing atas } \\
\text { dan passing bawah, dalam } \\
\text { hal ini guru } \\
\text { memperhatikan indicator } \\
\text { yang diamati pada siswa } \\
\text { sebagai berikut: } \\
\text { Posisi kaki } \\
\text { Posisi badan } \\
\text { Sikap lengan pada saat } \\
\text { perkenaan bola } \\
\text { Gerakan lanjutan }\end{array}$ & $\sqrt{ }$ & \\
\hline $\mathrm{c}$ & $\begin{array}{l}\text { Guru menugaskan pada } \\
\text { siswa untuk } \\
\text { mengulangkan kembali } \\
\text { cara melakukan Passing } \\
\text { atas dan passing bawah } \\
\text { secara kelompok. } \\
\text { Kegiatan Penutup } \\
\text { Formasi Barisan } \\
\text { Penilaian (Evaluasi atas } \\
\text { materi yang diajarkan) } \\
\text { Pendinginan }\end{array}$ & $\begin{array}{l}\sqrt{ } \\
\sqrt{ }\end{array}$ & $\sqrt{ }$ \\
\hline
\end{tabular}

Berikut disajikan dalam

bentuk tabel 2 hasil pengamatan kemampuan siswa siklus I.

Tabel 2 Hasil Pengamatan Kemampuan Siswa Siklus I

\begin{tabular}{|c|l|c|}
\hline No. & \multicolumn{1}{|c|}{ Uraian } & $\begin{array}{c}\text { Hasil } \\
\text { Siklus I }\end{array}$ \\
\hline \hline 1. & $\begin{array}{l}\text { Nilai rata-rata tes } \\
\text { formatif }\end{array}$ & 75,32 \\
\hline 2. & $\begin{array}{l}\text { Jumlah siswa yang tuntas } \\
\text { belajar }\end{array}$ & 18 \\
\hline 3. & $\begin{array}{l}\text { Persentase ketuntasan } \\
\text { belajar }\end{array}$ & 72,00 \\
\hline
\end{tabular}


Dari tabel di atas dapat rencana pelaksanaan pembelajaran dijelaskan bahwa dengan menerapkan dengan memperhatikan revisi pada pembelajaran inovatif modifikasi bola siklus I, sehingga kesalahan atau diperoleh nilai rata-rata hasil belajar kekurangan pada siklus I tidak terulang siswa adalah 75,32 dan ketuntasan lagi pada siklus II.

belajar mencapai $72,00 \%$ atau ada 18 Pengamatan kegiatan siklus II siswa dari 23 siswa yang telah tuntas dilakukan secara oleh peneliti dan guru belajar. Hasil tersebut menunjukkan kolabolator, dalam hal ini guru bahwa pada siklus pertama secara kolaborator sendiri yang bertindak klasikal siswa belum tuntas belajar, sebagai guru pengamat. Kegiatan karena siswa yang memperoleh nilai $\geq$ peneliti siswa selama proses 75 hanya sebesar $72,00 \%$ lebih kecil pembelajaran berlangsung diamati dari persentase ketuntasan yang melalui lembar pengamatan guru dan dikehendaki yaitu sebesar $85 \%$.

Hasil refleksi yang dilakukan oleh peneliti dan teman sejawat dapat dijelaskan sebagai berikut: (a) Guru perlu menyampiakan kompetensi belajar dan langkah-langkah pembelajaran yang dilakukan; dan (b) Sebagai umpan balik guru perlu memberikan beberapa pertanyaan yang relevan dengan materi yang telah disajikan.

\section{Siklus II}

Pelaksanaan kegiatan belajar mengajar untuk siklus II dilaksanakan pada tanggal 26 Februari 2017 di kelas $\mathrm{V}$ jam ke 1 dan 2 dengan jumlah siswa 23 siswa. Dalam hal ini peneliti bertindak sebagai guru. Adapun proses belajar mengajar mengacu pada lembar pengamatan siswa. Berikut disajikan pada table 4.3 hasil pengamatan kegiatan guru siklus I .

Tabel 3 Hasil Observasi Kegiatan Guru Siklus II

\begin{tabular}{|c|c|c|c|}
\hline \multirow{2}{*}{$\begin{array}{l}\mathrm{N} \\
\mathrm{o}\end{array}$} & \multirow{2}{*}{ Aspek Yang Diamati } & \multicolumn{2}{|c|}{ Dilaksanakan } \\
\hline & & $\mathrm{Ya}$ & Tidak \\
\hline $\mathrm{A}$ & $\begin{array}{l}\text { Kegiatan Pendahuluan } \\
\text { 1. Formasi Barisan } \\
\text { 2. Berdoa } \\
\text { 3. Absensi } \\
\text { 4. Pemanasan }\end{array}$ & $\begin{array}{l}\sqrt{ } \\
\sqrt{ } \\
\sqrt{ } \\
\sqrt{ }\end{array}$ & \\
\hline B & $\begin{array}{l}\text { 5. Guru menjelaskan } \\
\text { tentang Passing } \\
\text { atas dan passing } \\
\text { bawah dalam } \\
\text { permainan bola } \\
\text { voli } \\
\text { 6. Guru melatih cara } \\
\text { melakukan } \\
\text { Passing atas dan } \\
\text { passing bawah, } \\
\text { dalam hal ini guru } \\
\text { memperhatikan } \\
\text { indicator yang } \\
\text { diamati pada } \\
\text { siswa sebagai } \\
\text { berikut: Pasisi kaki } \\
\text { 5. Poriki badan } \\
\text { 6. Posisi lengan } \\
\text { 7. Sikap } \\
\text { pada saat }\end{array}$ & $\sqrt{ }$ & \\
\hline
\end{tabular}




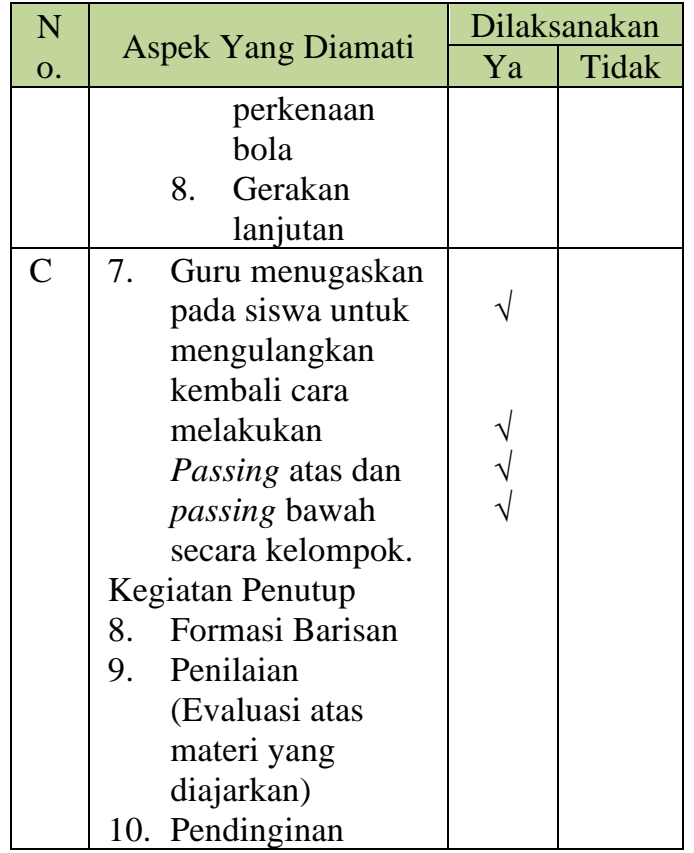

Berikut disajikan dalam

bentuk tabel 4 hasil pengamatan kemampuan siswa siklus II.

Tabel 4 Hasil Tes Formatif Siklus II

\begin{tabular}{|c|l|c|}
\hline No. & \multicolumn{1}{|c|}{ Uraian } & $\begin{array}{c}\text { Hasil } \\
\text { Siklus II }\end{array}$ \\
\hline \hline 1. & $\begin{array}{l}\text { Nilai rata-rata tes } \\
\text { formatif }\end{array}$ & 84,92 \\
\hline 2. & $\begin{array}{l}\text { Jumlah siswa yang } \\
\text { tuntas belajar }\end{array}$ & 23 \\
\hline 3. & $\begin{array}{l}\text { Persentase ketuntasan } \\
\text { belajar }\end{array}$ & 92,00 \\
\hline
\end{tabular}

Dari tabel di atas dapat

dijelaskan bahwa dengan menerapkan pembelajaran inovatif modifikasi bola diperoleh nilai rata-rata hasil belajar siswa adalah 84,92 dan ketuntasan belajar mencapai $92,00 \%$ atau ada 23 siswa dari 25 siswa yang telah tuntas belajar. Hasil tersebut menunjukkan bahwa pada siklus pertama secara klasikal siswa belum tuntas belajar, karena siswa yang memperoleh nilai $\geq$ 75 hanya sebesar $92,00 \%$ lebih kecil dari persentase ketuntasan yang dikehendaki yaitu sebesar $85 \%$.

Pada tahap ini akah dikaji apa yang telah terlaksana dengan baik maupun yang masih kurang baik dalam proses belajar mengajar dengan penerapan belajar aktif. Dari data-data yang telah diperoleh dapat duraikan sebagai berikut: Selama proses belajar mengajar guru telah melaksanakan semua pembelajaran dengan baik. Meskipun ada beberapa aspek yang belum sempurna, tetapi persentase pelaksanaannya untuk masing-masing aspek cukup besar. Berdasarkan data hasil pengamatan diketahui bahwa siswa aktif selama proses belajar berlangsung. Kekurangan pada siklussiklus sebelumnya sudah mengalami perbaikan dan peningkatan sehingga menjadi lebih baik. Hasil belajar siswa pada siklus II mencapai ketuntasan.

\section{Pembahasan}

Dari hasil pengamatan pelaksanaan tindakan siklus I ini secara keseluruhan proses pembelajaran dengan menggunakan inovatif modifikasi bola belum ada peningkatan hasil belajar siswa dalam materi Permainan bola besar/Bola voli passing 
atas dan passing bawah. Berdasarkan hasil tes evaluasi pada siklus I, masih ada beberapa siswa yang tidak bisa melakukan tehnik passing atas dan passing bawah. Namun hasil pengamatan pelaksanaan tindakan siklus II ini secara keseluruhan proses pembelajaran dengan menggunakan model pembelajaran Permainan bola besar/Bola voli passing atas dan passing bawah ada peningkatan hasil belajar siswa. Untuk lebih jelas dapat dilihat pada table di bawah ini.

Tabel 5 Perkembangan Hasil Belajar Siswa

\begin{tabular}{|c|l|c|l|}
\hline \multirow{2}{*}{ Pembelajaran } & Rata- & \multicolumn{2}{|l|}{ Ketuntasan } \\
\cline { 3 - 4 } & Rata & Jumlah & Persen \\
\hline Siklus I & 75,32 & 18 & $72,00 \%$ \\
& & & \\
\hline Siklus II & 84,92 & 23 & $92,00 \%$ \\
& & & \\
& & & \\
\hline
\end{tabular}

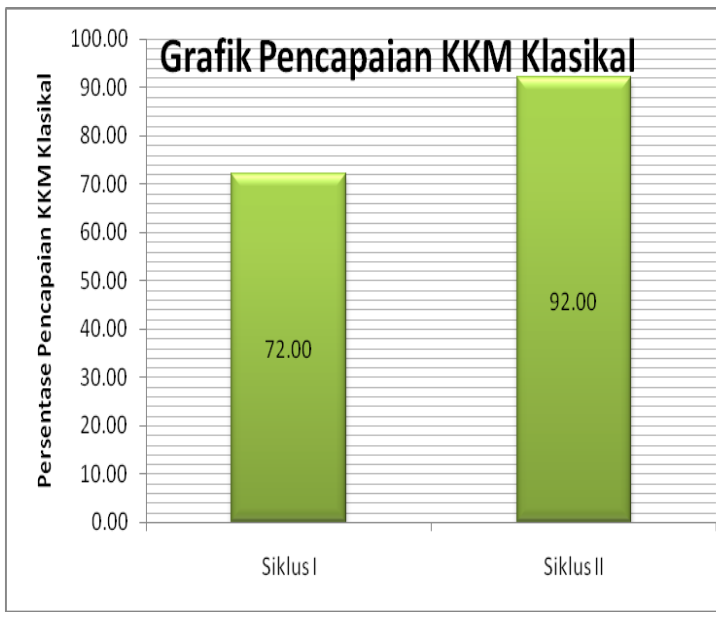

Grafik 1 Pencapaian KKM Klasikal

\section{KESIMPULAN}

Dari hasil kegiatan pembelajaran yang telah dilakukan selama dua siklus, dan berdasarkan seluruh pembahasan serta analisis yang telah dilakukan dapat disimpulkan bahwa pembelajaran dengan metode Inovatif Modifikasi Bola memiliki dampak positif dalam meningkatkan hasil belajar siswa yang ditandai dengan peningkatan ketuntasan belajar siswa dalam setiap siklus, yaitu siklus I $(72,00 \%)$ dan siklus II $(92,00 \%)$.

Dari hasil penelitian yang diperoleh dari uraian sebelumnya agar proses belajar mengajar PJOK lebih efektif dan lebih memberikan hasil yang optimal bagi siswa, maka disampaikan saran sebagai berikut: Guru harus mampu menentukan atau memilih topik yang benar-benar bisa diterapkan dengan model Inovatif Modifikasi Bola dalam proses belajar mengajar sehingga diperoleh hasil yang optimal. Guru pendidikan jasmani, olahraga dan kesehatan (PJOK) dituntut untuk kreatif dalam mengelola pembelajaran. Mulai dari awal pembelajaran sampai akhir pembelajaran. Ketika memberikan materi bahan ajar guru sangat terbantu dengan adanya media ajar. 
DAFTAR PUSTAKA

Ahmadi,Nuril.2007. Panduan Olahraga

Bola Voli. Solo: Era Pustaka

Utama

Alwi, Hasan. 2007. KBBI, edisi ketiga. Jakarta: Balai Pustaka.

Arif Syarifuddin dan Muhadi. 1991.

Pendidikan Jasmani. Jakarta:

Depdikbud. Drijendikti.

Proyek Pembinaan Tenaga

Kependidikan.

Depdiknas. 2003. Undang-Undang No.

20 Tahun 2003, tentang

Sistem Pendidikan Nasional.

Jakarta : Depdiknas.

Ibrahim, Rusli. 2001. Landasan

Psikologis Pendidikan

Jasmani di Sekolah. Dasar.

Depertemen Pendidikan

Nasional.

Suharno. 1982. Dasar-dasar Permainan

Bolavoli. Yogyakarta: FPOK

IKIP Yogyakarta.

Sukidin, Basrowi, Suranto. 2007.

"Manajemen Penelitian

Tindakan Kelas", Jakarta: :

Insan Cendekia.
Sulham, Najib. 2006. Pembangunan

Karakter pada Anak:

Manajemen Pembelajaran.

Syah dan Kariadinata.2009. Bahan

Pelatihan Pembelajaran Aktif, Inovatif, Kreatif, Efektif dan Menyenangkan (PAIKEM). Bandung: UIN Sunan Gunung Djati

Undang- undang RI No 3 Tahun 2005 Tentang Sistem Keolahragaan Nasional. Kementrian.Negara Pemuda dan Olahraga Republik Indonesia 